\title{
Doppler Radar Observation of a Tornado Generated Over the Japan Sea Coast during a Cold Air Outbreak
}

\author{
Fumiaki KOBAYASHI, Yukari SUGIMOTO, Tomoyuki SUZUKI \\ Department of Geoscience, National Defense Academy, Yokosuka, Japan \\ Takeshi MAESAKA \\ National Research Institute for Earth Science and Disaster Prevention, Tsukuba, Japan \\ and \\ Qoosaku MOTEKI
}

Agency for Marine-Earth Science and Technology, Yokosuka, Japan

(Manuscript received 11 May 2006, in final form 26 February 2007)

\begin{abstract}
On January 18, 2001, a tornado formed over the Japan Sea near the Mikuni Town on the Hokuriku Coast of Japan. The "Mikuni Tornado" formed within a winter thundercloud, during a period of a cold air outbreak, and heavy snowfall. The detailed structure of the tornado funnel cloud, and misocyclone within the cloud are revealed from photographs, videotape, Doppler radar data, and the GPS sonde data. The tornado was generated $3 \mathrm{~km}$ offshore, close to the radar site. The tornado formed at the edge of a developing cell, had a single funnel, and was accompanied by a misocyclone near the cloud base; the position of the misocyclone corresponded well with a funnel cloud. The misocyclone had a diameter of 400-800 m and vorticity of $10^{-1} \mathrm{~s}^{-1}$, and coincided with the tornado funnel vortex in the cloud base. The funnel cloud had diameters of $150 \mathrm{~m}$ at the cloud base and $30 \mathrm{~m}$ near the surface, and a vorticity of $10^{0} \mathrm{~s}^{-1}$. Although the funnel diameter at the cloud base changed remarkably during the life cycle of the tornado, the diameter near the surface remained largely unchanged. The funnel cloud began to dissipate after landing. The maximum wind speed of the tornado vortex is estimated to have been approximately $30 \mathrm{~ms}^{-1}$ (F0-scale), and the lifetime of the funnel cloud was 7 minutes. No damage or strong winds were recorded at the coastal radar site, which was located about $1 \mathrm{~km}$ from the tornado. The environmental feature that generated the Mikuni Tornado was vertical wind shear of the sub-cloud layer $\left(3.5 \times 10^{-2} \mathrm{~s}^{-1}\right)$. The tornado was a non-supercell type tornado that formed under the uniform winter monsoon. This result indicates that small-scale snowclouds can produce tornadoes during periods of cold air outbreaks.
\end{abstract}

\section{Introduction}

Tornadoes, and tornado-related disasters are common in Japan during all seasons, including

Corresponding author: Fumiaki Kobayashi, Department of Geoscience, National Defense Academy, Hashirimizu, Yokosuka 239-8686, Japan. E-mail: kobayasi@nda.ac.jp

(C) 2007, Meteorological Society of Japan supercell tornadoes, landspouts, and waterspouts. Supercell tornadoes that are accompanied by mesocyclones in the parent cloud are often reported in Japan (e.g., Kobayashi et al. 1996; Niino et al. 1993). Tornadoes are commonly accompanied by extratropical cyclones, typhoons and heat thunderstorms. For example, Suzuki et al. (2000) described a minisupercell tornado within the rainband of a 
typhoon. Many waterspouts (non-supercell tornadoes), occur near the coastline of Japan. Kobayashi et al. (1997) described the morphology and structures of waterspouts that formed over Tosa Bay on October 4, 1994. Tornadoes not only occur along the Pacific coast of Japan, but also along the Japan Sea coast during winter. Ishikawa Prefecture, on the Japan Sea side of Japan, has higher "tornado probability" value than many of the other prefectures located on the Japan Sea coast (Niino et al. 1997); however, the structure, morphology, and formative mechanism of wintertime tornadoes that form over the Japan Sea remain largely unknown.

The characteristics of wintertime convective cloud systems (wintertime mesoscale convective systems (MCSs) or winter thunderclouds) contrast strongly with those of the summer MCSs. One of the features of winter thunderclouds is small-scale echo cells with "single flash". Another feature is the existence of meso-scale vortices, the so-called "meso-low", with an active cloud band. Mesoscale disturbances that form within the Japan Sea Convergence Zone (JPCZ; Asai 1988) are important for forecasting heavy snowfall in the Hokuriku area. Ninomiya et al. (1996) described the multi-scale features of cold air outbreaks; however, the meso- $\gamma$-scale and micro-scale structures of such disturbances are poorly understood. In addition, the structure of tornadic disturbances is not well known. This paper presents a case study of a tornado observed on the Hokuriku Coast during an intensive observation period in winter. In Sec. 2 , we will introduce field observations undertaken along the Hokuriku Coast. Synoptic situations are shown in Sec. 3, and the structure of the Mikuni Tornado is described in Sec. 4. Finally, in Sec. 5 we will consider the environmental conditions that favor the generation of winter tornadoes. Tornadoes that form over the Japan Sea during winter are herein referred to as "winter tornadoes."

\section{Observations}

\subsection{Observation project for winter mesoscale convective systems over the Japan Sea}

An intensive observation project, from the middle of December 2000 until the end of January 2001, was undertaken to monitor various wintertime weather disturbances over the Ja-

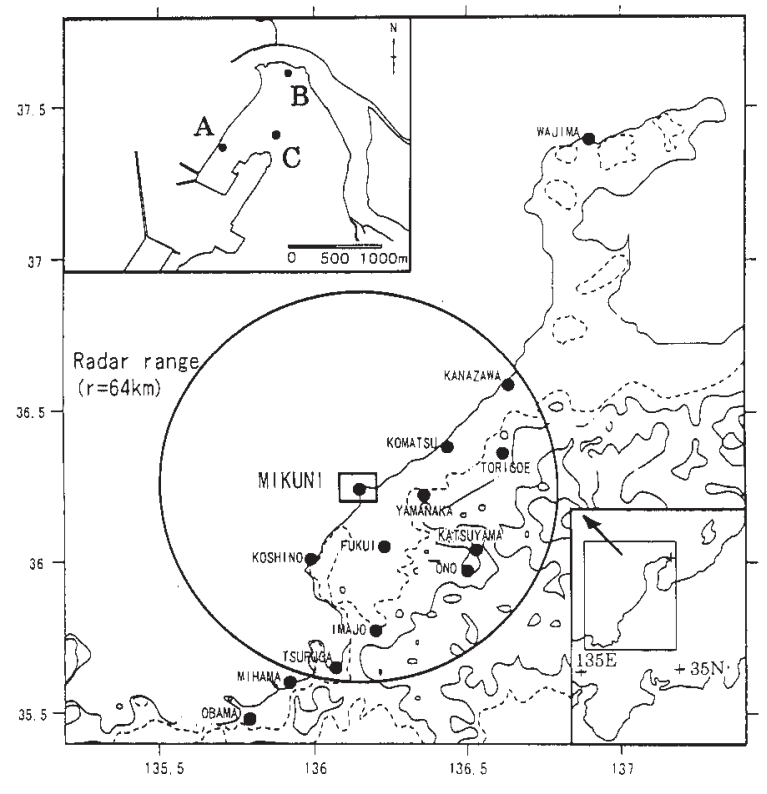

Fig. 1. Location map, geographical features, and radar range of the Mikuni site (circle). Contour lines denote $250 \mathrm{~m}$ (dashed line), $500 \mathrm{~m}, 1000 \mathrm{~m}$, and $1500 \mathrm{~m}$ (solid line). Solid circles represent meteorological stations of the Japan Meteorological Agency (JMA). Inset shows the observation site at Mikuni. Letters A, B and C denote the observation sites.

pan Sea. This project was named the Winter MCSs Observations over the Japan Sea-2001 (WMO-01; see Yoshizaki et al. 2004). Seven mobile Doppler radars were set up along the coastline, while the GPS sonde and wind profiler sites were established to enable routine upperair observations. Missions by observation ships and aircraft were also scheduled during the intensive observation period. Details of the project are provided by Yoshizaki et al. (2001, 2002, and 2003) and Kobayashi et al. (2003).

Figure 1 shows the observation area at Mikuni, near Toujinbou in Fukui Prefecture, Japan. The Doppler radar of the National Defense Academy (hereafter termed the NDA radar) was set up on the coastline to observe the fine structure of MCSs and the precipitation process that accompanies the landing of snowclouds (site A in Fig. 1). GPS sondes were launched at 3- or 6-hour intervals at site A. Surface weather stations, which automatically 
Table 1. Specifications of the NDA radar.

\begin{tabular}{|ll|}
\hline \multicolumn{2}{|c|}{ Specifications of NDA radar } \\
\hline Frequency & $9.7 \mathrm{GHz}$ \\
\hline Wavelength & $3.2 \mathrm{~cm}$ \\
\hline Minimum sensitivity (intensity) & $13 \mathrm{dBZ}$ \\
\hline Beam width & $1.2^{\circ}$ \\
\hline Spatial resolution (radial direction) & $125 \mathrm{~m}$ \\
\hline
\end{tabular}

measure meteorological elements, were established at three sites (sites A, B, and C). Doppler sodar (NDA, site A), Boundary Layer Radar, cloud radar (Kyoto University, site C), Cband dual-polarization Doppler radar (Hokuriku Electric Power Company, site A), and UHF Interferometer, which is a type of Lightning Location System (LLS) used to detect lightning strikes (Osaka University, site B), were also set up within the observation area.

\subsection{Doppler radar observations}

The NDA Doppler radar observations were conducted at Mikuni from the middle of December 2000 until the end of January 2001, to investigate the landing of winter thunderclouds. The NDA Doppler radar was set up just $50 \mathrm{~m}$ from the shore (site A in Fig. 1). A $64 \mathrm{~km}$ range was chosen to obtain data with high spatial resolution. This range encompasses the east side of Wakasa Bay, Echizen Cape, Komatsu City, and the Kanazawa City. The specifications of the NDA radar are listed in Table 1.

Doppler radar observations were carried out by plan position indicator (PPI) volume scans (10 elevations from 1.0 to $17.0^{\circ}$ ) and range height indicator (RHI) scan (azimuth of $300^{\circ}$ ) at 6-minute intervals. As there were no seaward obstacles, unobstructed radar detection was possible. Daytime cloud images were also captured by time-lapse video and $35 \mathrm{~mm}$ still photography during periods of snowcloud approach. Sampling of precipitation particles was carried out at the landing of snowclouds.

\section{Synoptic situation}

A surface pressure pattern involving a high to the west, and a low to the east, indicated that the winter monsoon blew over Japan (Fig. 2 ). A meso- $\alpha$-scale low of $1018 \mathrm{hPa}$ formed on

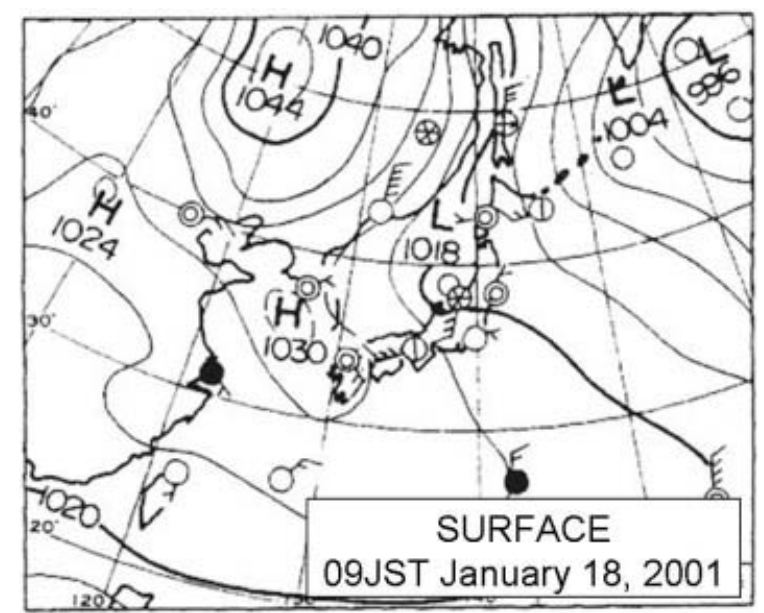

Fig. 2. Surface weather chart at 0900 JST on January 18, 2001 provided by JMA.

the west side of Hokuriku and passed over the study area on 18 January. As an upper-level $(500 \mathrm{hPa})$ cold air mass, with temperature below $-30^{\circ} \mathrm{C}$, covered the Japan Sea, snowfall was observed intermittently at the radar site. Figure 3 shows a geostationary meteorological satellite (GMS) visible image recorded at 1100 Japan Standard Time (JST), at the time of tornado formation. Cloud streak is evident over the central region of the Japan Sea, and a cloud mass corresponding to the meso- $\alpha$-scale low was observed from the eastern part of Hokuriku to the Tohoku area in the northern part of Honshu Island. After the passage of the meso$\alpha$-scale low, a band-shaped cloud formed around the Hokuriku Coast. This east-west oriented cloud band pattern lasted for several hours. The tornado formed in the area of cell-like cloud.

Figure 4 shows vertical profiles of temperature and relative humidity (left), and wind (right), close to the time and location of tornado generation. The height of the cloud top $(3 \mathrm{~km})$ was estimated from the vertical changes in relative humidity and wind speed. The wind speed at $1.5 \mathrm{~km}$ ASL (midlevel within the snowcloud) was about $15 \mathrm{~ms}^{-1}$. Although wind speed, and wind direction were largely uniform within the cloud, vertical wind shear was considerable, corresponding to a distinct change in wind speed below $1 \mathrm{~km}$ in height. 


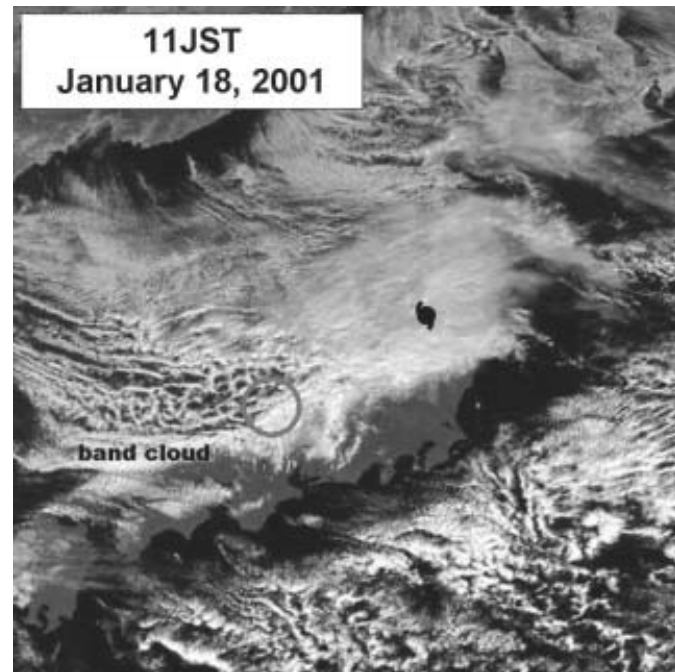

Fig. 3. GMS visible image recorded at 1100 JST on January 18, 2001 provided by JMA. A circle and a vortex mark denote radar range at Mikuni, and the position of the low, respectively.
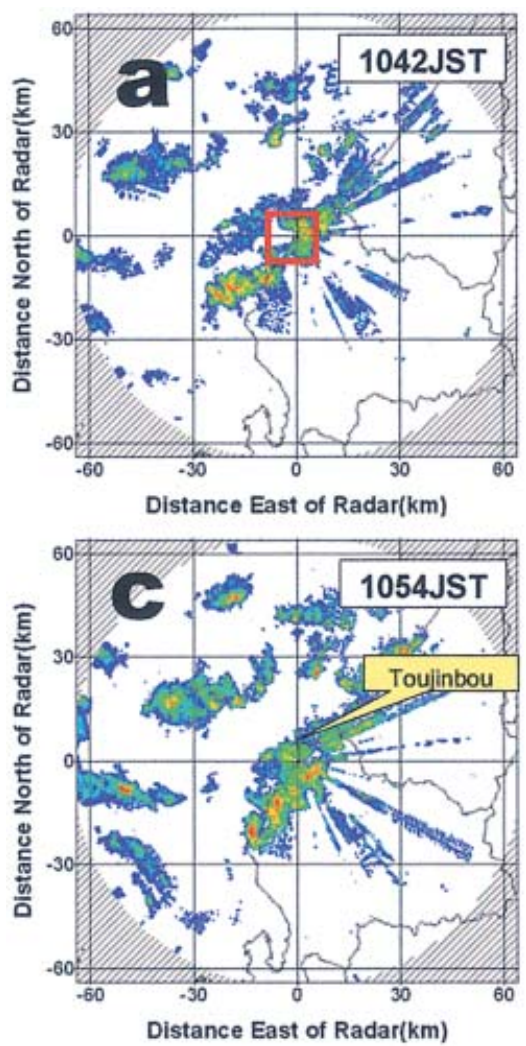

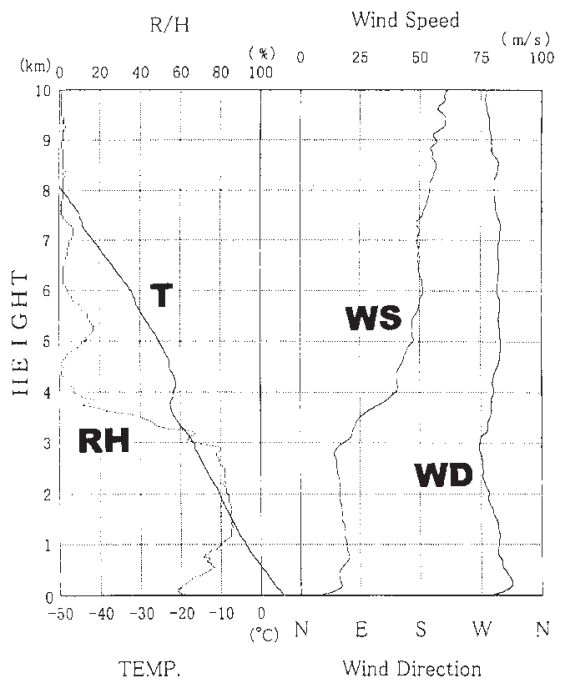

Fig. 4. Vertical profiles of temperature $(\mathrm{T})$, relative humidity $(\mathrm{RH})$, wind speed (WS), and wind direction (WD) recorded at the Mikuni site at 0900 JST, January 18, 2001, prior to formation of the tornado.
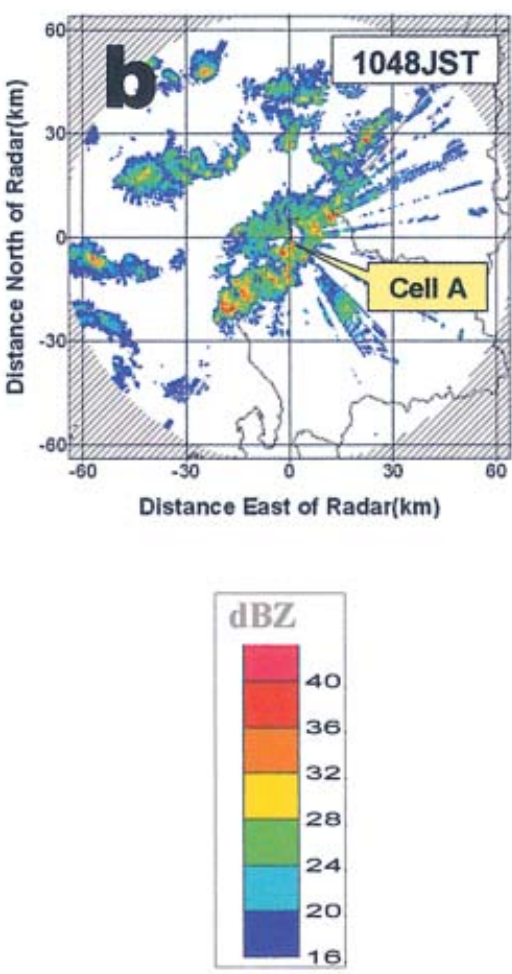

Fig. 5. Time sequence of radar echo images (reflectivity) from 1042 JST to 1054 JST (CAPPI 1 km). Square denotes the region expanded in Fig. 12. 

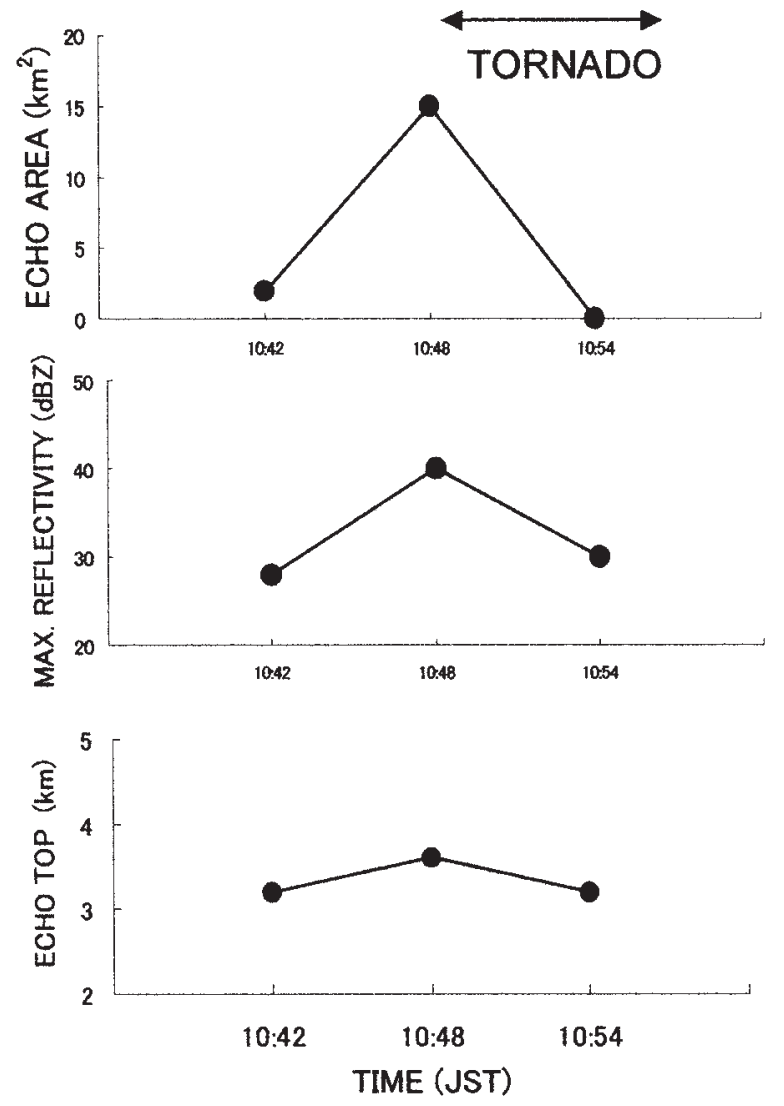

Fig. 6. Temporal changes in the radar echo area larger than $28 \mathrm{dBZ}$ (top), maximum reflectivity (middle), and height of radar echo (bottom).

\section{Structure of the Mikuni Tornado}

\subsection{Radar echo structure}

Figure 5 shows a time sequence of NDA radar echo patterns (reflectivity) of CAPPI (Constant Altitude of PPI) at $1 \mathrm{~km}$ height. Cell-like radar echoes were scattered over the Japan Sea at this time, and several cells with strong echo cores (exceeding $32 \mathrm{dBZ}$ ) were observed along the coastline. This echo system corresponded with the band-shaped cloud that formed behind the meso- $\alpha$-scale low. An echo cell (cell A) of about $5 \mathrm{~km}$ in diameter developed after 1042 JST, and landed approximately $5 \mathrm{~km}$ to the south of the radar site (1048 JST); the cell dissipated rapidly after landing (1054 JST).

Figure 6 shows the temporal changes of the radar echo area exceeding $28 \mathrm{dBZ}$, maximum reflectivity, and the echo top height for echo

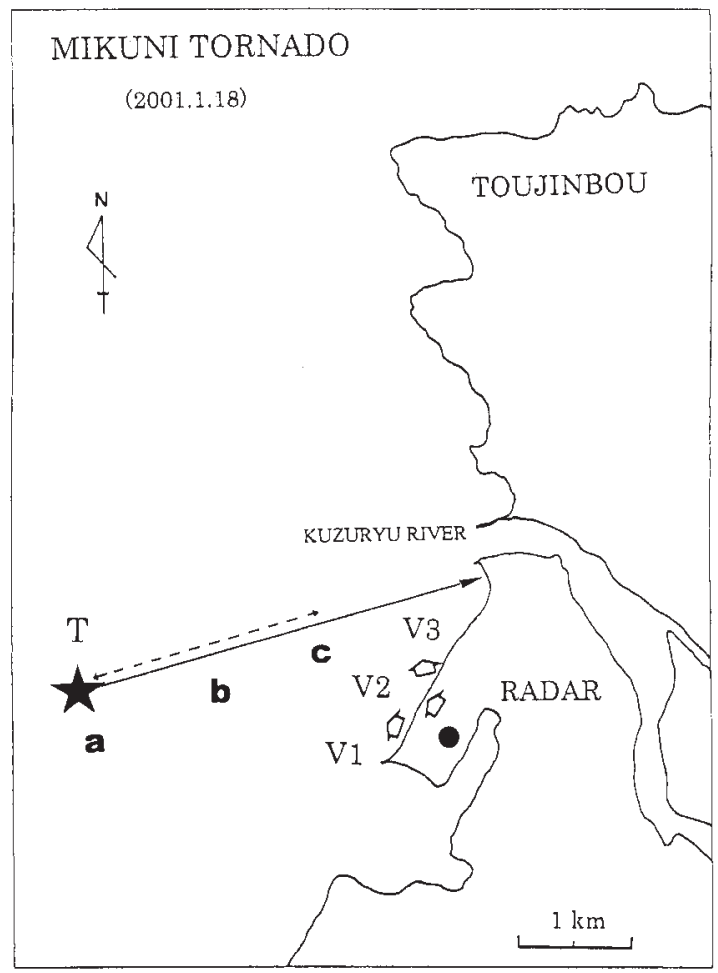

Fig. 7. Path of the Mikuni Tornado. The solid and dashed lines show the entire tornado path, and the limit of the tornado vortex observed by radar, respectively. V1-V3 denote the locations and viewing directions of the video cameras. Letters a-c on the map denote the positions of the funnel cloud corresponding to the three video images $(\mathrm{a}-\mathrm{c})$ shown in Fig. 8.

cell A. The core of the echo cell developed rapidly at landing (1048 JST); the lifetime of the echo cell was about 20 minutes, whereas the lifetime of the Mikuni Tornado was about 7 minutes (from 1048 to 1055 JST). The landing cell had a maximum reflectivity core of more than $40 \mathrm{dBZ}$, which included graupel particles of $5 \mathrm{~mm}$ in diameter, according to the sampling at the radar site. Wind gusts were observed by the surface weather data at the time of the cell landing; however, the echo top was only $3 \mathrm{~km}$ in height (the maximum value in the mature stage was $3.5 \mathrm{~km}$ at $1048 \mathrm{JST}$ ), which is the typical value for periods of midwinter cold air outbreaks over the Japan Sea. Just before landing the cell, a tornado formed at the northwest edge of the cell (area of weak echo or no echo). 


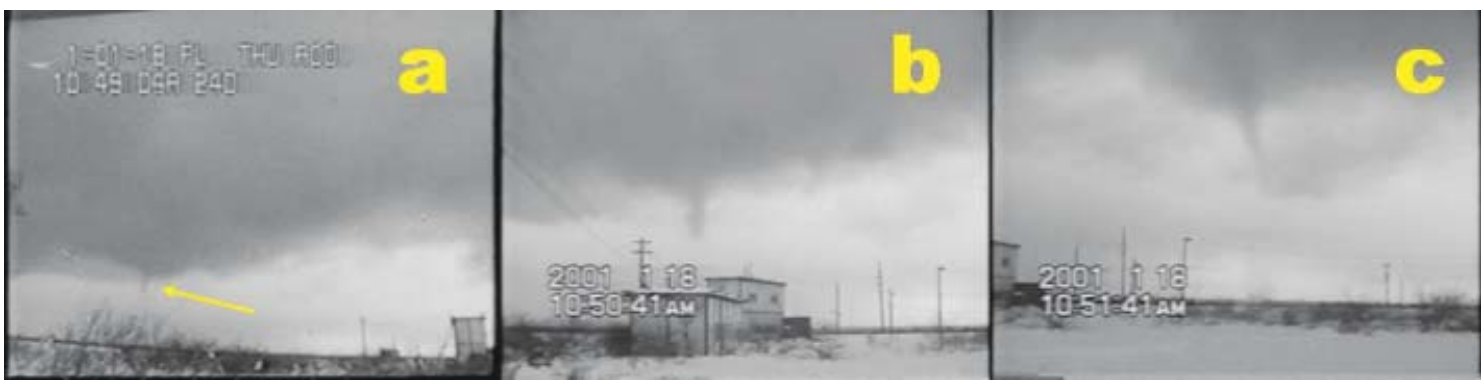

Fig. 8. Three video still images showing the three stages of the tornado: a) generation stage (1049:08 JST); b) developing stage (1050:41 JST); and c) mature stage (1051:41 JST).
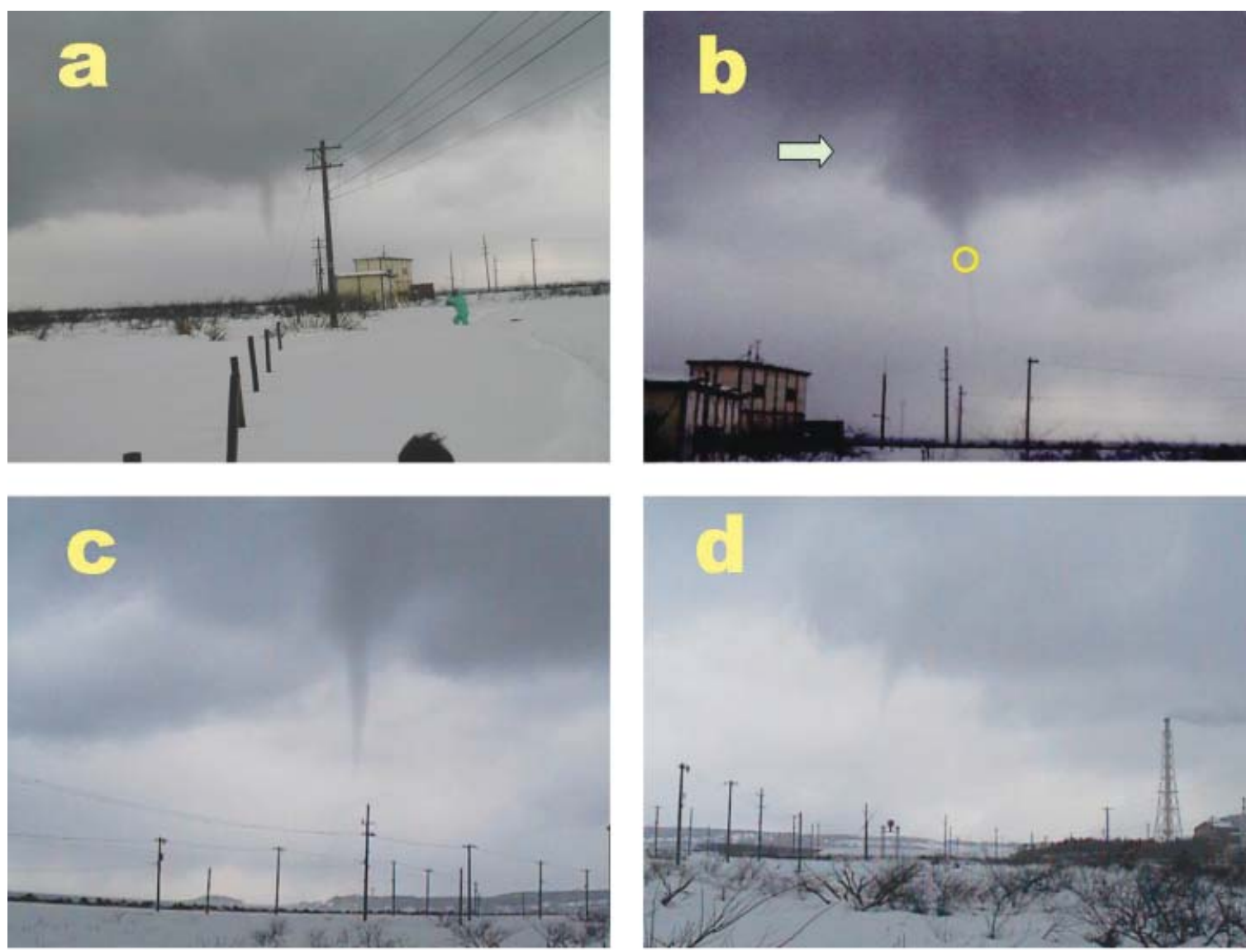

Fig. 9. Time sequence photographs of the tornado funnel. (a) Developing stage after the formation of the tornado funnel at 1050:30 JST (image taken by camera V1 in Fig. 7). (b) Mature stage just after touchdown at 1051:30 JST (V2 ). An arrow denotes a wall cloud. A circle denotes the radar beam resolution at the tornado location, $3 \mathrm{~km}$ from the radar site. (c) Mature stage before landing at 1052:00 JST (camera V3). (d) Disappearance of the funnel at 1053:00 JST. 


\subsection{Funnel cloud}

The shape of a tornado funnel cloud, from its generation to its disappearance, was observed by the two fixed video cameras (V1 and V3), the hand-held video camera (V2), and hand-held cameras (V1-V3 in Fig. 7). Dual-video observations indicate that the tornado was formed $3 \mathrm{~km}$ offshore, close to the radar site. Video images of the funnel (Figs. 8a-c), reveal three stages of the tornado that correspond to points $(\mathrm{a}-\mathrm{c})$ in Fig. 7: a generation stage at 1049 JST (arrow in Fig. 8a), a developing stage at 1050 JST (Fig. 8b), and a mature stage at 1051 JST (Fig. 8c).

Figure 9 provides photos of the tornado from the generation stage to its disappearance. Figure 9a shows the Mikuni Tornado funnel after its formation (1050:30 JST; viewed in the V1 direction shown in Fig. 7). Figure 9b shows the funnel cloud during the mature stage, 3 minutes after the tornado funnel formed (1051:30 JST; viewed in the V2 direction). The tornado touched down about 3 minutes after the tornado funnel formed, as confirmed by a water spray rising into the air near the sea surface (Fig. 8c). The tornado funnel had a spearheadshape at this time. A "wall cloud" was observed at the cloud base (about $300 \mathrm{~m}$ above sea level (ASL); arrow in Fig. 9b), indicating the existence of a parent vortex (misocyclone referred to by Fujita 1981). The height of the cloud base was visually observed by the GPS sonde observation at $0900 \mathrm{JST}$. After touching down, the funnel diameter began to shrink (1052:00 JST; Fig. 9c, as viewed in the V3 direction in Fig. 7). The funnel landed at 1052 JST, and the funnel cloud began to dissipate. Finally, the funnel cloud retreated upward at the mouth of the Kuzuryu River (1053:00 JST; Fig. 9d).

The lifetime of the funnel cloud was $7 \mathrm{~min}$ utes (1048-1055 JST). The changing diameter of the funnel cloud was estimated from captured images. The maximum funnel diameter was about $150 \mathrm{~m}$ at the cloud base and 20$30 \mathrm{~m}$ near the sea surface. The maximum wind speed, which was determined from the video images, was estimated to be about $30 \mathrm{~ms}^{-1}$ (F0-scale). The direction of rotation of the tornado was cyclonic.

\subsection{Scale of the Mikuni Tornado}

Figure 10 shows the temporal evolution of the funnel diameter at the cloud base, and

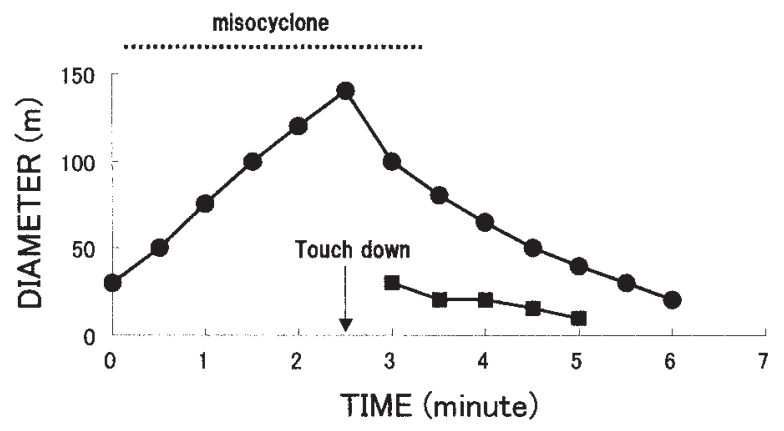

Fig. 10. Temporal changes in funnel diameter at the cloud base (-) and near the surface ( $\boldsymbol{\square})$ from 1048 JST (0 minute).

near the surface as estimated from video images. The diameter at the cloud base increased at a steady rate from 1048 JST (0 minutes) to 1051 JST (3 minutes). After touching down, the diameter decreased rapidly. The diameter near the surface was largely uniform throughout the entire life cycle of the tornado. In contrast to the behavior of larger supercell tornadoes observed in the USA (e.g., Golden and Purcell 1978), no remarkable changes in funnel diameter were observed near the surface.

The tornado was generated $3 \mathrm{~km}$ offshore, and moved in an ENE direction, corresponding to the movement of the cell, before disappearing at the mouth of the Kuzuryu River. The path length of the tornado was about $3 \mathrm{~km}$ (Fig. 7), which corresponded to P1-path length scale, according to the FPP scale. The movement speed of the funnel was about $7 \mathrm{~ms}^{-1}$, which was similar to the speed of the surface wind and slower than that of the cell motion $\left(15 \mathrm{~ms}^{-1}\right)$. There was no tornado-related damage to ships or mainland sites, and strong winds related to the tornado were not recorded at the radar site. Figure 11 shows the time sequences of the surface weather elements of pressure, temperature, wind direction, and wind speed at the radar site (site A in Fig. 1). There was no considerable change in meteorological elements before or after the tornado landing, except for wind direction, which changed from $\mathrm{S}$ to $\mathrm{W}$. These results suggest the absence of a mesocyclone, with a diameter of about $10 \mathrm{~km}$.

Radar data were collected by 10 elevationvolume scans, and the RHI scan at 6-minute in- 

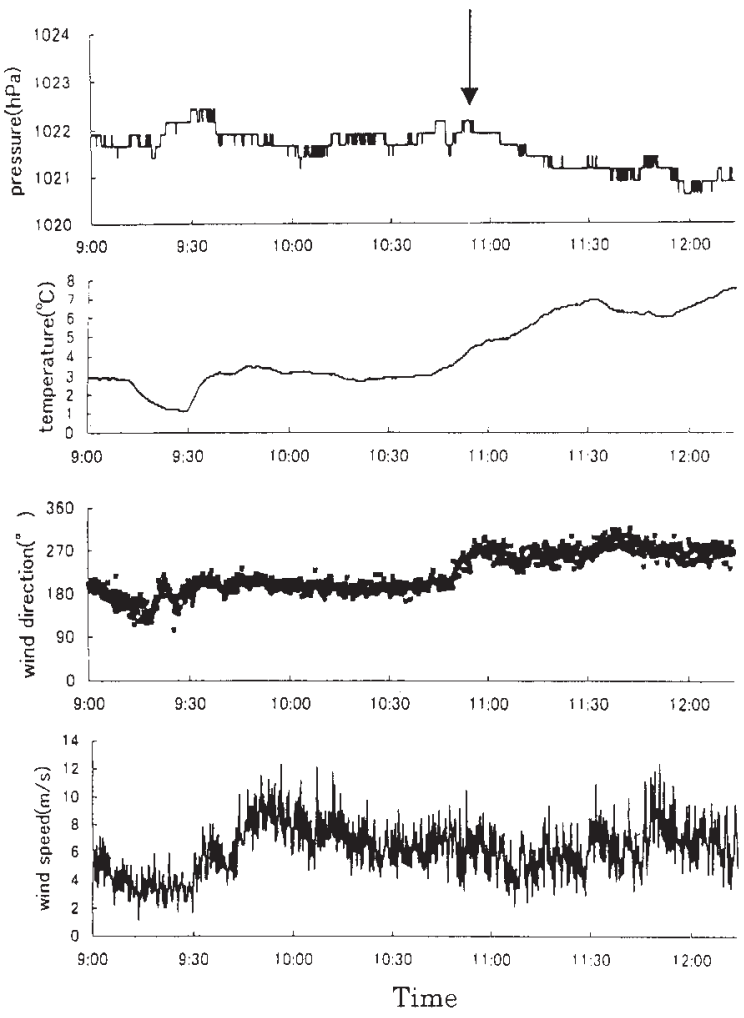

Fig. 11. Temporal changes in the meteorological elements of pressure, temperature, wind direction, and wind speed measured at 10 -second intervals at the Mikuni site from 0900 to 1230 JST on January 18, 2001. An arrow denotes the landing time of the Mikuni Tornado.

tervals. The tornado vortex was captured by a PPI volume scan from 1048 JST (elevation $\left.(\mathrm{EL})=1^{\circ}\right)$ to $1051 \mathrm{JST}\left(\mathrm{EL}=19^{\circ}\right)$. Figure 12 shows the Doppler velocity pattern at 1049 JST $\left(\mathrm{EL}=5^{\circ}\right)$, just after the generation of the tornado. The positive and negative peaks in the Doppler velocity indicate the presence of a circulation of $200 \mathrm{~m}$ in diameter. These observations indicate the existence of a vertical vortex in a horizontally uniform and strong winter monsoon wind (about $15 \mathrm{~ms}^{-1}$ of westerly wind in the cloud, as shown in Fig. 4). The estimated maximum wind speed (F0-scale), which is supported by the Doppler radar observations shown in Fig. 12. The approaching peak wind speed of more than $20 \mathrm{~ms}^{-1}$, corresponds to F0
(17-32 $\mathrm{ms}^{-1}$ ) in the scale of maximum wind speed. The spatial resolution of the radar beam was about $30 \mathrm{~m}$ at the location of the tornado, which was $3 \mathrm{~km}$ from the radar site (circle in Fig. 9b). It is therefore possible to discuss the detailed structure of the tornado.

Figure 13 shows five sequential PPI Doppler velocity patterns: (a) at $63 \mathrm{~m}$ ASL $\left(\mathrm{EL}=1^{\circ}\right)$, (b) $160 \mathrm{~m}$ ASL $\left(\mathrm{EL}=3^{\circ}\right)$, (c) $310 \mathrm{~m}$ ASL $\left(\mathrm{EL}=7^{\circ}\right)$, (d) $400 \mathrm{~m}$ ASL $\left(\mathrm{EL}=11^{\circ}\right)$, and (e) $430 \mathrm{~m}$ ASL $\left(\mathrm{EL}=15^{\circ}\right)$. Circulations were observed at each level, and all moved to the east. The position and movement of the tornado vortex, observed by Doppler radar, corresponds well with those of the funnel observed by cameras (Figs. 8 and 9). The fine structure of the Doppler velocity pattern at the lowest level $(63 \mathrm{~m}$ ASL; $\left.\mathrm{EL}=1^{\circ}\right)$ represented the positive $\left(7 \mathrm{~ms}^{-1}\right)$ and negative $\left(15 \mathrm{~ms}^{-1}\right)$ peaks in Doppler velocity (Fig. 14a). This vortex signature indicated the presence of a circulation of $60 \mathrm{~m}$ in diameter, and corresponded with the position of the tornado funnel, as shown in Fig. 9. Wide arrows in Fig. 14a denote the positions of maximum and minimum approaching Doppler velocity. This signature implies the presence of the misocyclone of about $600 \mathrm{~m}$ in diameter. Figure $14 \mathrm{~b}$ shows a schematic plan view of the Mikuni Tornado, compiled from the tornado vortex signatures shown in Fig. 14a.

Figure 15 shows the vertical distribution of the diameter and vorticity of the tornado vortex, as calculated from the Doppler radar data assuming that the tornado vortex remained steady during each radar volume scan (2.5 minutes). The diameter of the vortex varied sharply at three different altitudes: near the surface; below the cloud base; and, within the cloud. The diameter determined from the Doppler radar corresponds well with the diameter of the funnel cloud from the surface to the cloud base, as shown in Fig. 10. The remarkable change in the vortex diameter, that occurred at the cloud base corresponds to the tornado funnel below the cloud base, and a misocyclone (parent vortex) within the cloud. The vorticity calculated from peak-to-peak Doppler velocity by assuming axially symmetric vortex, was about $0.8 \mathrm{~s}^{-1}$ near the surface, and decreased with increasing altitude. The vorticity reached close to $10^{0} \mathrm{~s}^{-1}$ near the surface (funnel cloud), and was uniform (on the order of $10^{-1} \mathrm{~s}^{-1}$ ) near 


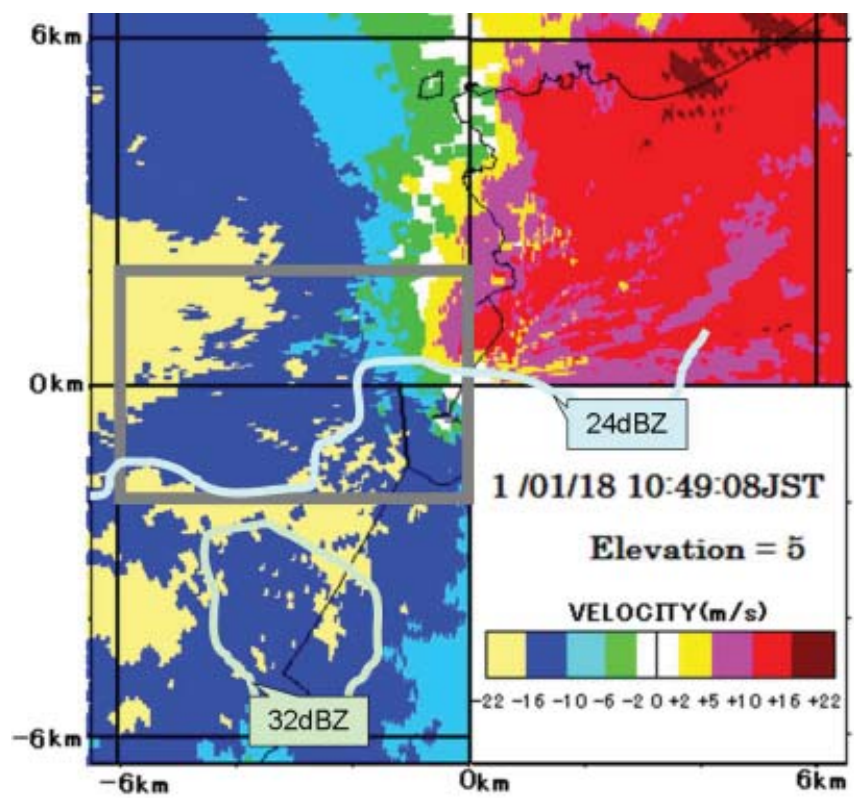

Fig. 12. Doppler velocity pattern $\left(\mathrm{EL}=5^{\circ}\right)$ at 1049 JST for the rectangular area shown in Fig. 5 . Solid lines denote radar reflectivity of $24 \mathrm{dBZ}$ and $32 \mathrm{dBZ}$, respectively.

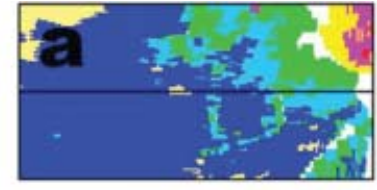

$\mathrm{EL}=1(63 \mathrm{~m})$ $10: 48: 10($ JST)

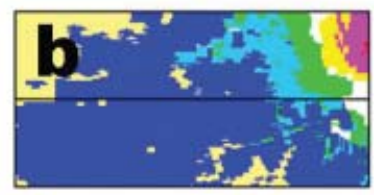

$\mathrm{EL}=3(160 \mathrm{~m})$ $10: 48: 48$

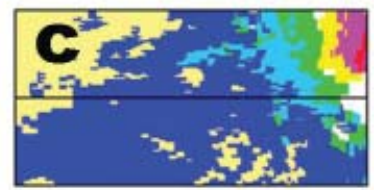

$\mathrm{EL}=7(310 \mathrm{~m})$ $10: 49: 27$

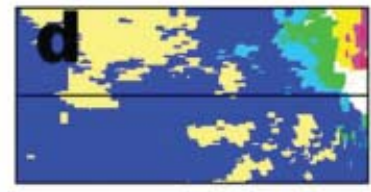

$\mathrm{EL}=11(400 \mathrm{~m})$ 10:50:04

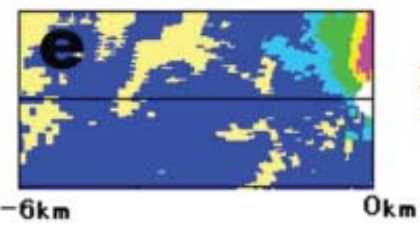

the cloud base and in the cloud. The angular momentum per unit mass calculated at each level in Fig. 15, was almost uniform $\left(\sim 1000 \mathrm{~m}^{2} \mathrm{~s}^{-1}\right)$ at all altitudes, indicating its conservation between the parent vortex (misocyclone) in the cloud, and the tornado vortex (funnel) below the cloud base (not shown). In this case, the tornado funnel and misocyclone may have formed simultaneously. The lifetime of the misocyclone was the same as that of the funnel cloud, as no vortex signature was observed in the volume scan data of the Doppler radar, once the funnel cloud had disappeared.

\section{Discussion}

The Mikuni Tornado appeared to occur within the cloud, whose circulation at the cloud base qualitatively resembles the air motions of the

Fig. 13. Five sequential PPI Doppler velocity patterns for the rectangular area shown in Fig. 12. (a) $\mathrm{EL}=1^{\circ}, 63 \mathrm{~m}$ ASL at 1048:10 JST. (b) $\mathrm{EL}=3^{\circ}$, $160 \mathrm{~m}$ at 1048:48 JST. (c) $\mathrm{EL}=7^{\circ}$, $310 \mathrm{~m}$ at 1049:27 JST. (d) $\mathrm{EL}=11^{\circ}$, $400 \mathrm{~m}$ at 1050:04 JST. (e) $\mathrm{EL}=15^{\circ}$, $430 \mathrm{~m}$ at 1050:42 JST. 

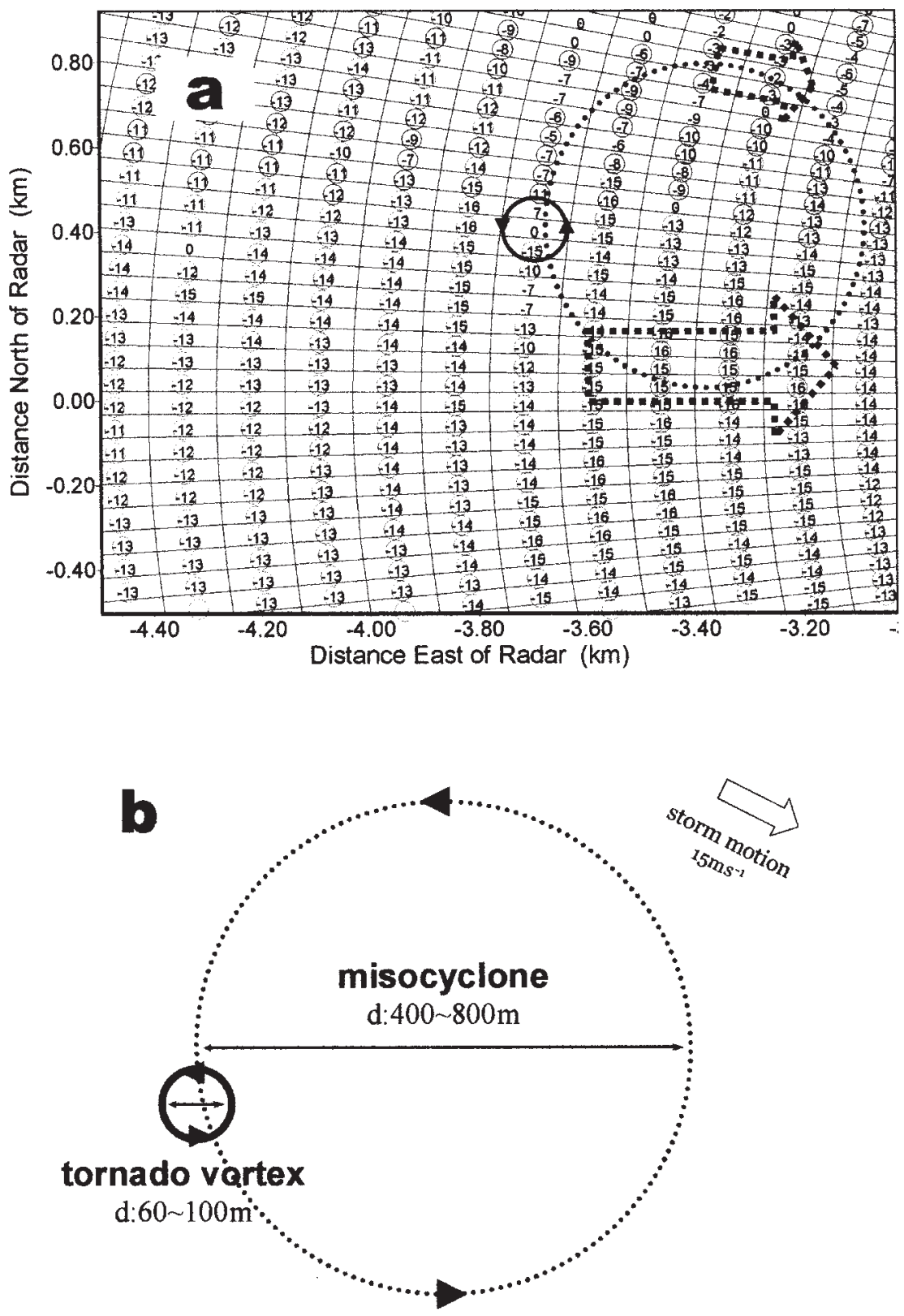

Fig. 14. (a) Values of Doppler velocity $\left(\mathrm{ms}^{-1}\right)$ around the tornado vortex at 1048 JST $\left(\mathrm{EL}=1^{\circ}\right)$. A circle and wide arrows (dotted circle) denote the position of the tornado vortex, and peak velocities of a misocyclone, respectively. (b) Schematic plan view of the tornado funnel vortex, and misocyclone.

wall cloud and misocyclones that occur within supercell-type storms in the USA. Many nonsupercell type tornadoes, known as landspouts and waterspouts, are known to form in association with cumulus congestus. The preexisting convergence line provides the vorticity in landspouts (e.g., Wakimoto and Wilson 1989), while the convergence line associated with a gust front provides the vorticity in waterspouts (e.g., Golden 1974).

Wakimoto and Wilson (1989) described a formation mechanism for non-supercell tornadoes that form along the shear line around Denver, USA. Two possible mechanisms for the forma- 

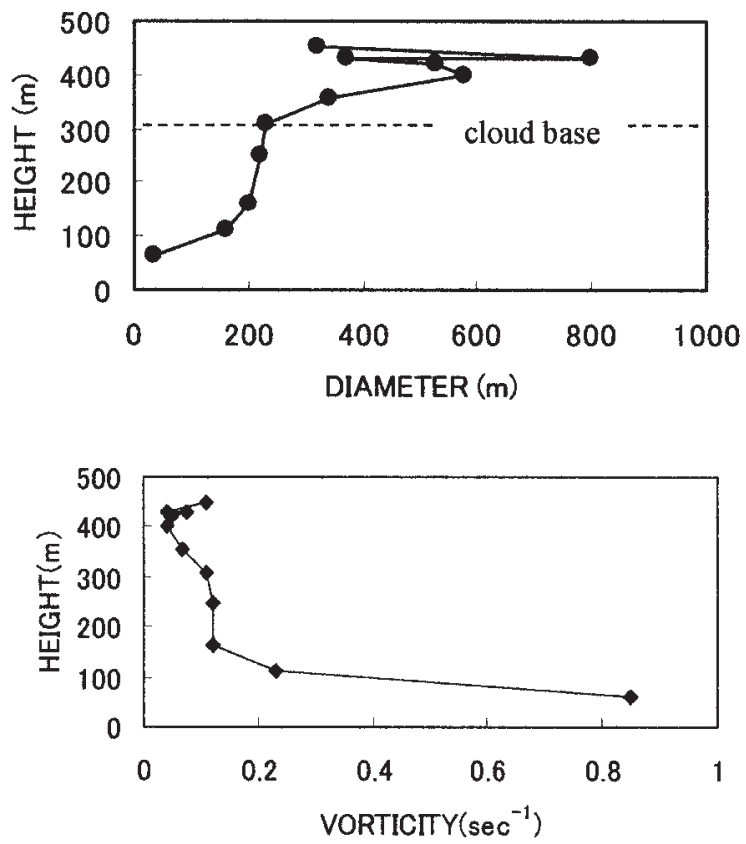

Fig. 15. Vertical variations in tornado diameter (top) and vorticity (bottom) calculated from respective Doppler velocity patterns, during 2.5 minutes.

tion of wintertime non-supercell type tornadoes over the Japan Sea are considered here: horizontal wind shear near the surface, and vertical wind shear below the cloud base. Over the Japan Sea, mesoscale disturbances form in the Japan Sea Convergence Zone (JPCZ). Nagata (1993) simulated meso- $\beta$-scale vortices, (30$50 \mathrm{~km}$ in diameter) that develop along the JPCZ cloud band. He concluded that barotropic shear instability is an important mechanism in the generation of the meso-vortex. This horizontal wind shear is an important environmental condition for the generation of winter tornadoes. In fact, tornadoes were also observed along the shear line on December 20, 1999 (Kobayashi 2003).

In the present case, large vertical shear in wind speed, occurred below the cloud base $(300 \mathrm{~m})$, as shown in Fig. 16. The vertical wind shear near the surface was extremely large at the time of tornado generation. The vertical wind shear was $3.5 \times 10^{-2} \mathrm{~s}^{-1}$ in the sub-cloud layer (below $300 \mathrm{~m}$ ), and $10.3 \times 10^{-3} \mathrm{~s}^{-1}$ below $1500 \mathrm{~m}$. On the basis of the above observations, a possible formation mechanism for the Mikuni

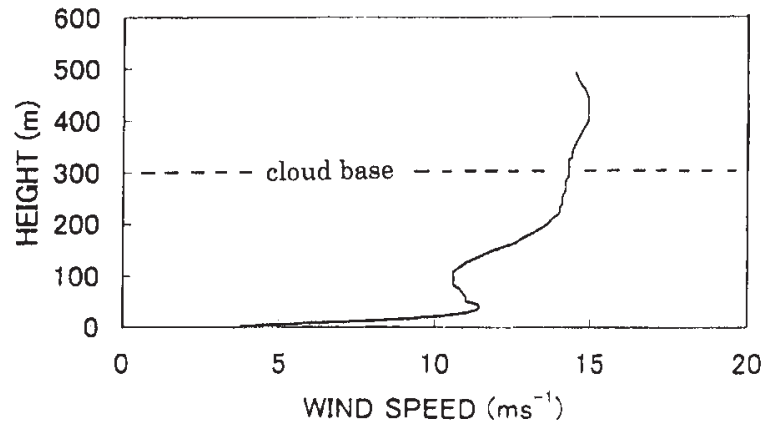

Fig. 16. Enlargement of the wind speed below the cloud base shown in Fig. 4.

Tornado involves a horizontal vortex tube, associated with the strong vertical shear in the sub-cloud layer. This environmental condition indicates that the snowcloud can readily produce a horizontal vortex tube below the cloud base under the strong winter monsoon wind. The horizontal vortex tube may have been tilted by the updraft of a developing wintertime thundercloud cells.

Using Doppler radar data, Donaldson (1970) examined the features of TVS (tornado vortex signature), and defined the mesocyclones as 1) having vorticity of more than $10^{-2} \mathrm{~s}^{-1}$ in the cloud, and 2) displaying temporal and vertical continuity within the vortex. As the tornado vorticity had a short lifetime of 7 minutes, and a small diameter of less than $1 \mathrm{~km}$, the Mikuni Tornado is considered not to have been accompanied by a mesocyclone, but with the misocyclone generated simultaneously in the parent cloud. The lack of change observed in the meteorological elements at the radar site, is due to the small size of the parent cloud (misocyclone). The misocyclone of the Mikuni Tornado had a diameter of about $0.7 \mathrm{~km}$. The tornado funnel passed about $1.5 \mathrm{~km}$ north of the radar site. Therefore, no changes in tornadic weather, or surface damage were observed at the radar site. Note that some winter tornadoes that are accompanied by a mesocyclone have caused considerable damage and led to remarkable changes in surface weather elements (Kobayashi et al. 1992).

Figure 17 shows the CG (Cloud-to-Ground) lightning distribution in the Hokuriku area from 1000 to 1200 JST on January 18, 2001. Active CG lightning was observed along the 


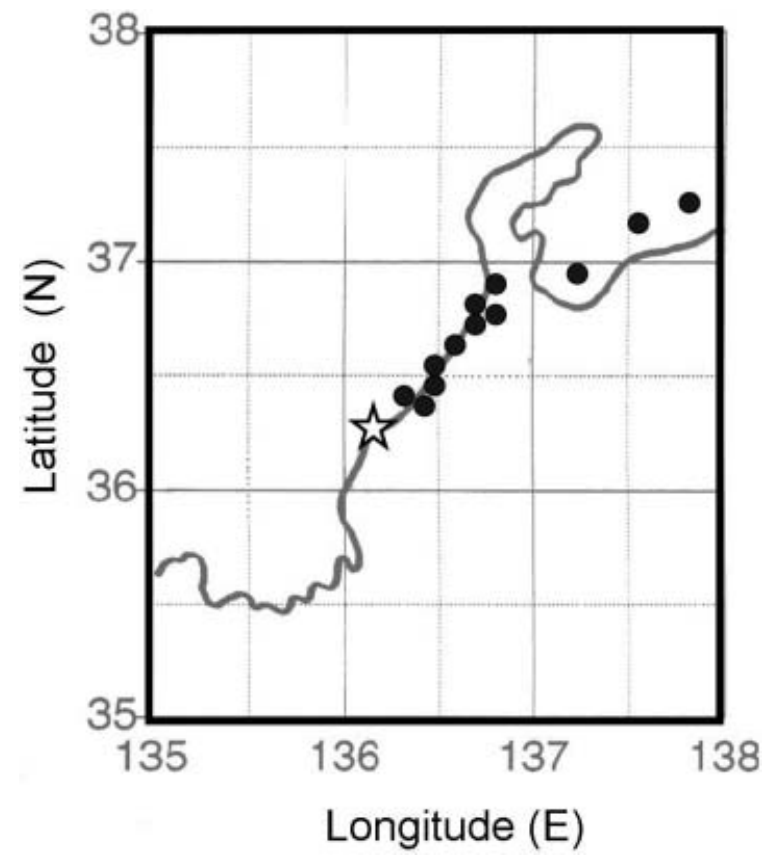

Fig. 17. CG (Cloud-to-Ground) lightning distribution around the Hokuriku area from 1000 JST to 1200 JST on January 18, 2001, observed by LLS (lightning location system). A star indicates the location of Mikuni.

coastline during this period. The frequency of active CG lightning was recorded during the morning of the day in which the tornado occurred. CG lightning was observed at a rate of about 10 strikes per hour, each occurring as a single flash. At 1106 JST, a CG lightning flash was observed around Mikuni; this corresponded with the development of a cell behind cell A. On January 18, a cold air mass of $-27^{\circ} \mathrm{C}$ was observed at a height of $5 \mathrm{~km}$, with the $-10^{\circ} \mathrm{C}$ level at $1.8 \mathrm{~km}$ height. A westerly wind was dominant at heights between 1 and $5 \mathrm{~km}$. The cloud top was estimated to be about $3 \mathrm{~km}$ in height, according to the GPS sonde data (Fig. 4). The echo top of cell A was about $500 \mathrm{~m}$ higher than those of other cells over the Japan Sea. One reason for the vigorous convective activity near the coastline is that cumulus convection was strengthened behind the meso$\alpha$-scale low. Lightning activity indicated strong updraft within the cloud, and the formation of graupel particles. Light snowfall (1-2 $\mathrm{mmh}^{-1}$ ) with graupel particles was observed at the ra- dar site during the passage of the meso- $\alpha$-scale low.

The formation of "steam devils" over Lake Michigan, USA, has been reported under conditions of a cold air outbreak (Lyons and Pease 1972). The formation mechanism of steam devils appears to be similar to that of dust devils generated over a desert. Thermal instability is also a necessary condition for the formation of winter tornadoes over the Japan Sea. The values of the environmental conditions of CAPE, helicity and bulk Richardson number, as defined by Bluestein and Jain (1985), calculated from the GPS sonde data at 0900 JST on 18 January, were $130 \mathrm{~m}^{2} \mathrm{~s}^{-2}, 0.46$ and 5.7 , respectively. Although these values are relatively small for cumulonimbus convection, compared with summer thunderstorm conditions in both Japan and the USA, winter thunderclouds develop under the cold air outbreaks. The Mikuni Tornado is therefore not considered to be a supercell-type tornado. Further studies are needed to accumulate data on the environmental conditions that favor the generation of winter tornadoes, especially factors such as stability, wind shear, and local wind fields.

\section{Concluding remarks}

The Mikuni Tornado formed in a snowcloud during a cold air outbreak period near the Hokuriku Coast (Mikuni Town) over the Japan Sea on January 18, 2001. This study is the first to document the structure and evolution of a "winter tornado" over the Japan Sea. The detailed structure of the tornado funnel cloud, and misocyclone within the cloud, was determined from photographs, videotapes, Doppler radar data, and the GPS sonde data that were observed close to the tornado. The characteristics of the Mikuni Tornado are summarized in Table 2.

The tornado was generated $3 \mathrm{~km}$ offshore, close to the radar site. The tornado formed at the edge of a developing cell and had a wall cloud and a funnel cloud. The tornado vortex was accompanied by a misocyclone near the cloud base, but was not accompanied by a mesocyclone. The location of the misocyclone corresponded to that of the funnel cloud; the misocyclone and funnel cloud may have formed concurrently. The misocyclone had a diameter of $400-800 \mathrm{~m}$ and vorticity of $10^{-1} \mathrm{~s}^{-1}$, corre- 
Table 2. Characteristics of the Mikuni Tornado.

\begin{tabular}{|c|c|}
\hline \multicolumn{2}{|c|}{ TORNADO } \\
\hline life time: & 7 minutes \\
\hline funnel width (maximum): & $\begin{array}{l}30 \mathrm{~m} \text { (near the surface) } \\
150 \mathrm{~m} \text { (cloud base) }\end{array}$ \\
\hline maximum wind speed: & $30 \mathrm{~ms}^{-1}$ \\
\hline vorticity: & $10^{0} \mathrm{~s}^{-1}$ \\
\hline damage: & no damage \\
\hline F-scale: & F0 \\
\hline FPP scale: & F0P1P1 \\
\hline \multicolumn{2}{|c|}{ PARENT CLOUD } \\
\hline life time: & 20 minutes \\
\hline horizontal scale: & $5 \mathrm{~km}$ \\
\hline maximum reflectivity: & $40 \mathrm{dBZ}$ \\
\hline mesocyclone: & no mesocyclone \\
\hline misocyclone: & $\begin{array}{l}400 \mathrm{~m} \sim 800 \mathrm{~m} \text { (cloud } \\
\text { base) }\end{array}$ \\
\hline vorticity: & $10^{-1} \mathrm{~s}^{-1}$ \\
\hline height of cloud top: & $3 \mathrm{~km}$ \\
\hline height of cloud base: & $300 \mathrm{~m}$ \\
\hline \multicolumn{2}{|c|}{ ENVIRONMENTAL CONDITIONS } \\
\hline CAPE: & $130 \mathrm{~m}^{2} \mathrm{~s}^{-2}$ \\
\hline Richardson number (Ri): & 5.7 \\
\hline Helicity $(\mathrm{H})$ : & 0.46 \\
\hline vertical wind shear: & $\begin{array}{l}3.5 \times 10^{-2} \mathrm{~s}^{-1}(\mathrm{sub}- \\
\text { cloud layer })\end{array}$ \\
\hline
\end{tabular}

sponded to the tornado funnel vortex within the cloud base. The funnel cloud had diameters of $150 \mathrm{~m}$ at the cloud base, and $30 \mathrm{~m}$ near the surface, with a vorticity of $10^{0} \mathrm{~s}^{-1}$. Although the funnel diameter changed remarkably at the cloud base during the life cycle of the tornado, the diameter near the surface remained unchanged. The funnel cloud began to dissipate after landing. The estimated maximum wind speed of the tornado vortex was about $30 \mathrm{~ms}^{-1}$ (F0-scale), and the lifetime of the funnel cloud was 7 minutes. No damage or strong winds were observed at the coastal radar site located about $1 \mathrm{~km}$ from the tornado. The environmental conditions that generated the Mikuni Tornado were characterized by strong vertical wind shear of the sub-cloud layer $\left(3.5 \times 10^{-2} \mathrm{~s}^{-1}\right)$. The Mikuni Tornado was a non-supercell type tornado that formed under the horizontally uniform winter monsoon. The results of the present study indicate that tornadoes can form from small-scale snowclouds (winter thundercloud cells) during periods of midwinter cold air outbreaks.

\section{Acknowledgments}

The authors wish to offer thanks to the members of the WMO-01 observation group, and the members who surveyed the tornado: Dr. M. Yoshizaki (Meteorological Research Institute (MRI)), Dr. T. Kato (MRI), Dr. T. Miyamoto (Osaka Electro-Communication University), Dr. H. Sugawara (NDA), and Mr. Y. Ueno (NDA). We express thanks to Dr. H. Iwasaki (Gunma University), and anonymous reviewers for their valuable comments. This observational study was supported by Core Research for Evolutional Science and Technology (CREST) of the Japan Science and Technology Corporation.

\section{References}

Asai, T., 1988: Meso-scale features of heavy snowfalls in Japan Sea coastal regions of Japan. Tenki, 35, 156-161 (in Japanese).

Bluestein, H.B. and M.H. Jain, 1985: Formation of mesoscale lines of precipitation: Severe squall lines in Oklahoma during the spring. J. Atmos. Sci., 42, 1711-1732.

Donaldson, R.J., Jr., 1970: Vortex signature recognition by a Doppler radar. J. Appl. Meteor., 9, 661-670.

Fujita, T.T., 1981: Tornadoes and downbursts in the context of generalized planetary scales. $J$. Atmos. Sci., 38, 1511-1534.

Golden, J.H., 1974: Life cycle of Florida Key's waterspouts. I. J. Appl. Meteor., 13, 676-692.

Golden, J.H. and D. Purcell, 1978: Life cycle of the Union City, Oklahoma tornado and comparison with waterspouts. Mon. Wea. Rev., 106,3-11.

Kobayashi, F., 2003: Doppler radar observation of winter tornadoes over the Japan Sea. Proceedings of $31^{\text {st }}$ International Conference on Radar Meteorology, Seattle, 613-616.

Kobayashi, F., O. Chiba, and A. Matsumura, 1997: Morphology and structure of waterspouts occurred over Tosa Bay on 4 October 1994. Tenki, 44, 19-34 (in Japanese with English abstract).

Kobayashi, F., K. Kikuchi, and H. Uyeda, 1996: Life cycle of the Chitose tornado of September 22, 1988. J. Meteor. Soc. Japan, 74, 125-140.

Kobayashi, F., G. Naito, and K. Michimoto, 1992: A tornado phenomenon associated with snowclouds over the Japan Sea in winter seasonTornadic damage in Kanazawa City on December 11, 1991. Proceedings of $12^{\text {th }}$ National 
Symposium on Wind Engineering, Tokyo, 5560 (in Japanese with English abstract).

Kobayashi, F., M. Yoshizaki, Y. Shibagaki, H. Hashiguchi, M. Teshiba, M. Murakami, and WMO-02 Observation Group, 2003: A report on "Winter MCSs (mesoscale convective systems) observations over the Japan Sea-2002 (WMO-02)." Tenki, 50, 385-391 (in Japanese).

Lyons, W.A. and S.R. Pease, 1972: "Steam Devils" over Lake Michigan during a January Arctic outbreak. Mon. Wea. Rev., 100, 235-237.

Nagata, M., 1993: Meso- $\beta$-scale vortices developing along the Japan-Sea polar airmass convergence zone (JPCZ) cloud band: Numerical simulation. J. Meteor. Soc. Japan, 71, 43-57.

Niino, H., O. Suzuki, H. Nirasawa, T. Fujitani, H. Ohno, I. Takayabu, N. Kinoshita, and Y. Ogura, 1993: Tornadoes in Chiba Prefecture on 11 December 1990. Mon. Wea. Rev., 121, 3001-3018.

Niino, H., T. Fujitani, and N. Watanabe, 1997: A statistical study of tornadoes and waterspouts in Japan from 1961 to 1993. J. Climate, 10, 1730-1752.

Ninomiya, K., J. Fujimori, and T. Akiyama, 1996: Multi-scale features of the cold air outbreak over the Japan Sea and the northwestern Pacific. J. Meteor. Soc. Japan, 74, 745-761.

Suzuki, O., H. Niino, H. Ohno, and H. Nirasawa, 2000: Tornado producing mini supercells associated with Typhoon 9019. Mon. Wea. Rev., 128, 1868-1882.
Wakimoto, R.M. and J.W. Wilson, 1989: Nonsupercell tornadoes. Mon. Wea. Rev., 117, 1113-1140.

Yoshizaki, M., H. Eito, S. Hayashi, T. Kato, K. Aonashi, M. Murakami, H. Kuroiwa, and H. Minda, 2003: A report on "Winter MCSs (mesoscale convective systems) observations over the Japan Sea-2003 (WMO-03)." Tenki, 50, 661-668 (in Japanese).

Yoshizaki, M., T. Kato, H. Eito, S. Hayashi, and W.-K. Tao, 2004: An overview of the field experiment 'Winter Mesoscale Convective Systems (MCSs) over the Japan Sea in 2001,' and comparisons of the cold-air outbreak case (14 January) between analysis and a nonhydrostatic cloud-resolving model. J. Meteor. Soc. Japan, 82, 1365-1387.

Yoshizaki, M., T. Kato, H. Eito, A. Adachi, M. Murakami, S. Hayashi, and WMO-01 Observation Group, 2001: A report on "Winter MCSs (mesoscale convective systems) observations over the Japan Sea-2001 (WMO-01).” Tenki, 48, 893903 (in Japanese).

Yoshizaki, M., T. Kato, C. Muroi, H. Eito, S. Hayashi, and CREST Observation Group, 2002: Recent activities of field observations on mesoscale convective systems (MCSs) over East China Sea and Kyushu in the Baiu season and over the Japan Sea in winter. Proceeding of International Conference on Mesoscale Convective Systems and Heavy Rainfall/Snowfall in East Asia, Tokyo, 80-85. 